\title{
Developing a Scale to Assess Teachers' Perceptions towards Using Web 2.0 Tools in Lectures (TPUWL Scale)
}

\author{
Bekir Yıldırım* \\ Faculty of Education, Muş Alparslan University, Muş, Turkey, \\ ORCID: 0000-0002-5374-4025
}

\section{Adem Akkuş}

Faculty of Education, Muş Alparslan University, Muş, Turkey, ORCID: 0000-0001-9570-3582

Article history

Received:

05.04.2020

Received in revised form: 29.05.2020

Accepted:

23.06.2020

Key words:

Web 2.0 tools;

teacher;

scale;

perception
Web 2.0 tools are the tools helping individuals share information online. Although there are scales which determine the opinions of teachers on using web 2.0 tools there is no scale developed to determine the perceptions of teachers towards using Web 2.0 tools. Thus, aim of this research was to develop a scale to assess the teachers' perceptions related to using Web 2.0 tools at lectures (TPUWL) and determine the factors affecting the perception of teachers. For scale development purpose data was gathered from 240 teachers. Exploratory factor analyses were carried out to find out the structure of the TPUWL. Analyses revealed that TPUWL's structure had two factors. First factor had 12 items and was entitled "Perception towards Using" while second factor had 10 items and was called "Professional Competence Perception". For confirmatory factor analyses data was gathered from 220 teachers. Thereupon, total sample of the study consisted of 460 teachers. Data analyses revealed that TPUWL scale is a reliable and valid assessment tool. Scale's Cronbach's alpha reliability coefficient was found as .95 . After confirming the validity and reliability of the scale, analyses were carried out to determine the factors which might affect the teachers' perceptions on using Web 2.0 tools with respect to age, education level, experience and gender factors. Analyses revealed that age, education level and experience factors had no statistically significant effect on teachers' perception toward using Web 2.0 tools. On the other hand, it was revealed by the study that gender factor had a statistically significant effect on the perception. As a consequence, it was determined by the researchers that TPUWL is a useful scale to determine the teachers' perception towards using Web 2.0 tools in lectures.

\section{Introduction}

Rapid changes in technology have caused dramatic changes on informatics sciences. As a result, different tools have been developed for users to access data and to use the data interactively. Web 2.0 is one of the tools developed for that purpose. The term was first

\footnotetext{
*Correspondency: bekir58bekir@gmail.com
} 
defined by Tim O'Reilly in 2004 (O'Reilly, 2005). Web 2.0 tools are the new generation of the web tools helping individuals to participate in the process of sharing information, commenting on information and interacting with other individuals (Ajjan \& Hartshorne, 2008; Horzum, 2010; O'reilly, 2005; Korucu \& Çakır, 2015). Web 2.0 tools include blogging, poster and concept map creations, assessment and evaluation tools, interaction on social networks, creating and editing videos (Aybat \& Doğan, 2017). Web 2.0 tools are also used in education due to their interactive features. Those features help students to acquire positive skills that enable meaningful learning, permanent learning, problem solving skills, critical thinking and working cooperatively (Korucu \& Yücel, 2015).

Studies indicate that the increasing trend of using web 2.0 tools creates a harmony between the individuals and assist them in sharing knowledge among themselves (Yan, Zha \& Yan, 2014). Even local governments use web 2.0 to share information and in return citizens shape the politicians' ideas (Rodriguez Bolivar, 2017). Such dramatic effects of web 2.0 tools naturally paved the way for their being situated in educational settings and hence researchers tried to determine the attitudes of teacher candidates towards using web 2.0 tools (Eyyam, Meneviş \& Doğruer, 2011). Other researchers tried to study the perceptions of students on the effectiveness of web 2.0 tools in higher education (Venkatesh, Croteau \& Rabah, 2014) while some of the researchers tried to determine the effect of gender on using web 2.0 tools in higher education (Huang, Hood \& Yoo, 2013).

Upon the integration of Web 2.0 tools into educational settings and with the integration of technology, teachers have become responsible agents of using those technologies (Akpinar, 2003). Due to those responsibilities teachers should have the necessary qualifications to use Web 2.0 tools. On the other hand, studies show that teachers lack enough efficiency in using Web 2.0 tools. (Blannin, 2015). For more efficient teaching, training on Web 2.0 tools should be given to teachers. But prior to the planning of such training sessions, having knowledge upon the perception of teachers on using Web 2.0 tools is important. That said, perceptions might be a subjective case. Thence, ideas pertaining to the notions of "right" and "wrong" might differ for each individual (Friman, 1999). Thusly researchers have to determine the different factors affecting the individuals' perceptions and assess these accordingly. In light of these, since perceptions might change through experiences, it is crucial to give training on web 2.0 tools and train teachers to use the tools efficiently. Here again, so as to be able to create experiences the need of knowing an individual's perception is essential. Literature already outputs that different measurement tools, such as scales, are being continuously used to determine the attitudes of individuals. In fact, different scales are being used to assess the attitudes of teachers (Birişçi et.al., 2018; Horzum \& Aydemir, 2014; Madden, Ellen \& Ajzen, 1992) in this regard. Several researchers tried to reveal in particular teachers' opinions related to using Web 2.0 tools. On the other hand, within our knowledge, there is not a scale developed to determine the perceptions of teachers' towards using Web 2.0 tools, (Anyanwu, 2012; Faize, Chiheb, \& Ee Afia, 2015; Yuen, Yaoyuneyong, \&Yuen, 2011; Zelick, 2013). Since no scale has been developed for assessing teachers' perceptions towards usage of web 2.0 tools, purpose of this study is to develop a scale to assess teachers' perception towards usage of web 2.0 tools and developing a scale to determine the effect of age, education level, experience and gender factors on perception of the teachers.

\section{Method}

Methodological research design is applied for the study to develop TPUWL scale since it is useful in sustaining data quality and also it is an appropriate approach in survey 
development or scale adaptation studies (Madans, 2001).

\section{Participants}

Study was carried out with two different groups and finalized within two months. The first study group consisted of 240 teachers, and the second group consisted of 220 teachers. The exploratory factor analysis (EFA) of the adapted scale was conducted via the data obtained from the first group. The confirmatory factor analysis (CFA) was implemented from the data of the second study group. The current study used differences of the two samples since repeating the study or re-doing the exploratory factor analysis or conducting a confirmatory factor analysis, or conducting two successive confirmatory factor analyses only with a sample may not validate the proposed structure (Y1ldirım, 2018). To validate the proposed structure demographics of the two samples are selected as closely as possible to each other. Table 1 shows the demographic characteristics of the two study groups (samples).

Table 1. Demographic Characteristics of Science Teachers for Two Analyses

\begin{tabular}{llllll}
\hline & & First Study Group & \multicolumn{2}{c}{ Second Study Group } \\
\hline Gender & & $\mathrm{N}$ & $\%$ & $\mathrm{~N}$ & $\%$ \\
& Male & 59 & 24.58 & 55 & 25 \\
Age & Female & 181 & 75.42 & 165 & 75 \\
& 20-30 years & 91 & 37.92 & 82 & 37.27 \\
Experience & 31-40 years & 109 & 45.42 & 101 & 45.91 \\
& 41- or more years & 40 & 16.66 & 37 & 16.82 \\
& 0-10 years & 135 & 56.25 & 124 & 56.36 \\
Educational Level & 11-20 years & 86 & 35.83 & 79 & 35.91 \\
& 21-or more years & 19 & 7.92 & 17 & 7.73 \\
& Bachelor & 176 & 73.33 & 163 & 74.09 \\
& Postgraduate & 54 & 22.50 & 49 & 22.27 \\
\hline
\end{tabular}

It is clear from Table 1 that teachers who are the sample of the study are mostly women, aged between 31-40, with experiences of 0-10 years and nearly a quarter of them have masters and few of them have $\mathrm{PhD}$ degrees.

\section{Development of the TPUWL Scale}

Taking a glance at the relevant literature five steps are followed to develop TPUWL scale to assess teachers' perceptions towards using web 2.0 tools in the lectures (Anyanwu, 2012; Horzum \& Aydemir, 2014; Yuen, Yaoyuneyong, \&Yuen, 2011; Zelick, 2013). Those steps are indicated in the Table 2.

Table 2. TPUWL Scale Development Steps

\begin{tabular}{|c|c|}
\hline Step & Procedure \\
\hline Step 1 & Extensive literature review on web 2.0 tools was conducted \\
\hline Step 2 & $\begin{array}{l}\text { Interviews conducted with } 12 \text { teachers whose opinions were asked through open ended } \\
\text { questions on web } 2.0 \text { tools }\end{array}$ \\
\hline Step 3 & $\begin{array}{l}\text { TPUWL scale was developed with } 30 \text { items having two themes; Perception towards Using } \\
\text { (PU) and Professional Competence Perception (PCP) }\end{array}$ \\
\hline Step 4 & $\begin{array}{l}\text { TPUWL scale was shared with three experts with a view to obtaining their opinions and taking } \\
\text { these into consideration }\end{array}$ \\
\hline Step 5 & $\begin{array}{l}\text { Draft TPUWL was administrated to } 10 \text { teachers. Finalized version consisted of } 22 \text { items which } \\
\text { are rated on a 5-point scale and administered to } 460 \text { teachers. }\end{array}$ \\
\hline
\end{tabular}




\section{Data analysis}

EFA and CFA were performed for data analyses of the TPUWL scale. 240 teachers were selected for exploratory factor analysis. Their responses to the TPUWL Scale were analyzed via SPSS 22TM software and the results of factor analysis and reliability were obtained. CFA was performed after the item and factor structure of the TPUWL scale was determined. Data from a second sample group (220 teachers) was obtained for confirmatory factor analysis. Both EFA and CFA were applied for the data obtained from study group for the TPUWL scale. Rating of the scale was determined as "good" since the total number of sample group is consisted of 460 teachers (Comrey \& Lee, 1992, p. 217). Additionally, literature suggests that sample size should be five to ten times larger than the number of items (Tavşancil, 2002), and since the present study's sample size was ten times larger than the number of items, it is thought that sampling is good enough to carry out factor analysis. Employing an orthogonal rotation strategy with varimax rotation technique helps researchers to interpret the results easily. To that end, using a varimax rotation for factor analysis considered logical for the current study and hence varimax rotation was used for factor analysis (Kieffer, 1998). For the confirmatory factor analysis, GFI, AGFI, RMSEA, CFI, SRMR, IFI and NFI were calculated.

\section{Findings}

Final version of TPUWL scale was applied to 240 teachers for EFA. For CFA data were collected from 220 teachers. Both EFA and CFA results are indicated in the next section.

\section{Findings on Scale's Validity \\ Exploratory factor analysis}

Kaiser-Meyer-Olkin (KMO) and Barlett tests were utilized to determine whether the data fit for EFA or not. The KMO value of 22 items was calculated as .94 and the Bartlett test result was found to be significant $(\chi 2=3431.326, \mathrm{df}=231, \mathrm{p}<.05)$. The results indicated that the data were appropriate for factor analysis since KMO coefficient was greater than 0.60 and the Bartlett test was significant (Büyüköztürk, 2006). Therefore, it is concluded that the data from Turkish science teachers were appropriate to run an EFA. EFA and the factor loadings of the items were conducted with the first study group to determine the factorial status of the scale.

Varimax analysis was performed for the TPUWL scale. Kaiser (1960) recommends considering the eigenvalues which are equal or greater than one (1) in choosing the factors. The results of the varimax analysis revealed that two factors have an eigenvalue greater than 1 for the TPUWL scale. This meant that the TPUWL scale had a two-factor structure. Scree plot results for the TPUWL scale are given in Figure 1. 


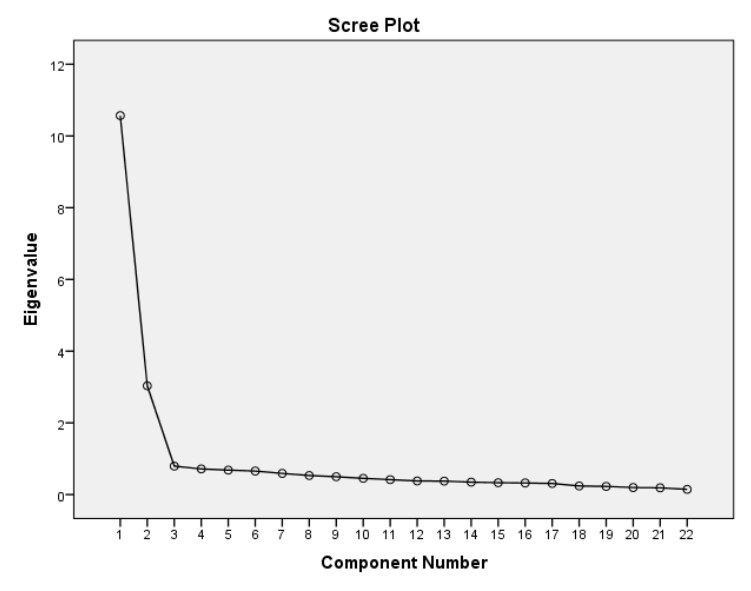

Figure 1. Scatter Graph

The results of the Exploratory Factor Analyis of the TPUWL scale are presented in Table 3.

Table 3. Results of the EFA of the TPUWL scale

\begin{tabular}{|c|c|c|c|c|c|}
\hline $\begin{array}{l}\text { Items } \\
\text { No } \\
\end{array}$ & Items & $\mathbf{M}$ & SD & $\begin{array}{l}\text { Factor } \\
\text { Load. }\end{array}$ & $\begin{array}{l}\text { Com. } \\
\text { (h2) }\end{array}$ \\
\hline \multicolumn{6}{|c|}{ Perception towards Using (PU) (12 items) } \\
\hline 26 & Web 2.0 tools increase technology literacy & 4.41 & .715 & .819 & .723 \\
\hline 24 & Web 2.0 tools help courses to be fun & 4.48 & .696 & .815 & .724 \\
\hline 33 & $\begin{array}{l}\text { Usage of Web } 2.0 \text { tools in an education environment is } \\
\text { important }\end{array}$ & 4.38 & .712 & .712 & .687 \\
\hline 32 & Web 2.0 tools offer an interactive learning environment & 4.44 & 660 & .793 & 664 \\
\hline 22 & Web 2.0 tools appeal more than one sense & 4.35 & .713 & .787 & 669 \\
\hline 23 & Web 2.0 tools provide permanent learning & 4.17 & .716 & .756 & 612 \\
\hline 13 & $\begin{array}{l}\text { Web } 2.0 \text { tools provide rich learning environments for the } \\
\text { students }\end{array}$ & 4.31 & .739 & .743 & .587 \\
\hline 27 & $\begin{array}{l}\text { Web } 2.0 \text { tools allow the teachers and students to share music, } \\
\text { pictures and videos. }\end{array}$ & 4.33 & 696 & .727 & .570 \\
\hline 10 & Web 2.0 tools increase creativity of students & 4.28 & 692 & .721 & 602 \\
\hline 25 & Web 2.0 tools provide concrete learning & 4.16 & .760 & .705 & .532 \\
\hline 15 & Web 2.0 tools increase attention of students towards courses & 4.26 & .712 & .702 & .555 \\
\hline 8 & $\begin{array}{l}\text { Web } 2.0 \text { tools are effective on gaining skills required for } \\
\text { professional life }\end{array}$ & 4.18 & .748 & .569 & .425 \\
\hline \multicolumn{6}{|c|}{ Professional Competence Perception (PCP) (10 items) } \\
\hline$\overline{12}$ & I can prepare educational materials related to Web 2.0 tools & 3.59 & .873 & .824 & .706 \\
\hline 1 & I can use Web 2.0 tools effectively & 3.85 & .879 & .815 & 698 \\
\hline 5 & I have enough information on Web 2.0 tools & 3.28 & .936 & .805 & .661 \\
\hline 3 & I can integrate Web 2.0 tools into my lesson plans & 3.57 & .817 & .761 & .594 \\
\hline 20 & I know how to use Web 2.0 tools at lectures & 3.75 & .864 & .757 & .653 \\
\hline 2 & I can assess and evaluate student learning via Web 2.0 tools & 3.85 & .806 & .740 & .640 \\
\hline 4 & $\begin{array}{l}\text { I can guess which one of the Web } 2.0 \text { tools is appropriate to } \\
\text { students' level }\end{array}$ & 3.81 & .783 & .731 & 600 \\
\hline 17 & I can answer students' questions related to Web 2.0 tools & 3.59 & .874 & .717 & .585 \\
\hline 11 & $\begin{array}{l}\text { I can integrate Web } 2.0 \text { tools into learning and instruction } \\
\text { process. }\end{array}$ & 3.92 & .791 & 684 & .635 \\
\hline 37 & I follow the developments on Web 2.0 tools & 3.78 & .943 & .635 & .477 \\
\hline
\end{tabular}

The percentages of the ranked variance quantities for PU, and Professional Competence Perception (PCP) were 48.035 and 13.783 respectively. These two factors share $61.818 \%$ of the total variance of the TPUWL scale. 12 items emerged under PU (factor loads of each item are between .569 and .819) and 10 items emerged under PCP (factor loads of each item are 
between .635 and .824$)$.

\section{Confirmatory factor analysis}

CFA results of the TPUWL scale are shown in Figure 2.

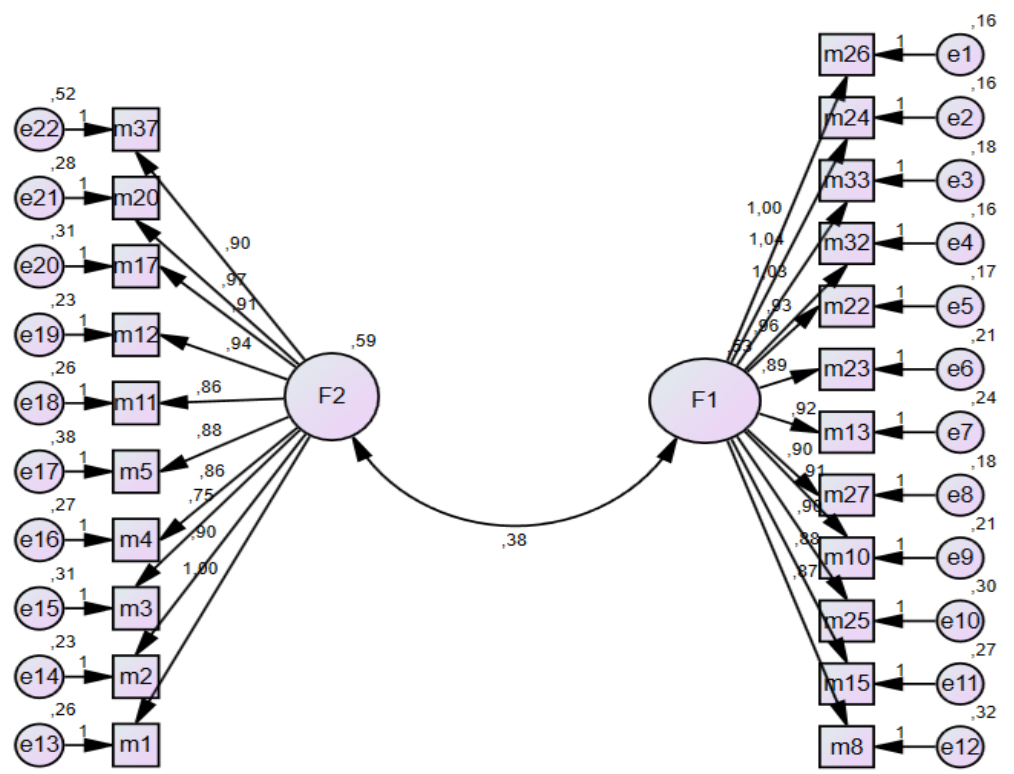

Figure 2. CFA results of the TPUWL scale

The model conformity of the TPUWL Scale were tested by criteria such as GFI, AGFI, RMSEA, CFI, SRMR, and NFI (Kılıç \& Şen, 2014). Chi-square $\left(\chi^{2}\right), \chi^{2} / \mathrm{SD}$, RMSEA, GFI and AGFI are commonly used in confirmatory factor analysis. In large samples, calculated $\chi 2 / \mathrm{df}$ ratio can also be used as a criterion for conformity adequacy. If calculated Chi-square $\left(\chi^{2}\right) /$ degree of freedom (df) ratio is smaller than 3 , it can be regarded as good fit; and if $\chi^{2} / \mathrm{df}$ ratio is smaller than 5, it can be regarded as sufficient (Yıldırım \& Selvi, 2015).

The findings showed that model data had a good fit since AGFI and GFI values were greater than 0.90 (Hooper, Coughlan, \& Mullen, 2008), IFI value was greater than 0.95 (Baumgartner \& Homburg, 1996; Bentler, 1980), RMSEA value was smaller than 0.05 (Jöreskog \& Sörbom, 1993). Model data fit is acceptable since AGFI $>0.80$; GFI $>0.85$ and both the RMSEA and RMR values > 0.080 (Anderson \& Gerbing, 1984; Hu \& Bentler, 1999). The confirmatory factor analysis results of the TPUWL scale are shown in Table 4.

Table 4. Fit Indices of TPUWL scale

\begin{tabular}{lllllllll}
\hline Chi Square & $\mathrm{p}$-value & CFI & NFI & GFI & AGFI & IFI & SRMR & RMSEA \\
\hline 2.025 & .00 & .94 & .90 & .85 & .81 & .94 & .040 & .072 \\
\hline
\end{tabular}

CFA results highly confirmed the structural equation and scale model. Chi-square value is highly affected by sample size and when sample size is good enough, probability of getting significant results increases. Chi-square value of the CFA was found significant which also indicated that sample size is good enough. Since $\chi 2$ and df ratio is lower than 3 , it might be said that model data fit is high. Additionally, IFI, CFI and NFI indicated that model-data fit is high since their values exceeds 0.90 and, RMSEA value was found as 0.0072 where AGFI and GFI also exceeded 0.80 and 0.85 in respective order. Results of CFA of TPUWL scale confirmed that scale has two sub-dimensions along with high model-data fit. 


\section{Item Factor Correlations}

Table 5. Item Factor Correlations

\begin{tabular}{llll}
\hline Factor 1: PU (12 items) & & Factor 2: PCP (10 items) & \\
\hline Items & Item-total correlation & Items & Item-total correlation \\
\hline I26 & .713 & $\mathrm{I} 12$ & .656 \\
$\mathrm{I} 24$ & .721 & $\mathrm{I} 1$ & .662 \\
$\mathrm{I} 33$ & .663 & $\mathrm{I} 5$ & .605 \\
$\mathrm{I} 32$ & .659 & $\mathrm{I} 3$ & .575 \\
$\mathrm{I} 22$ & .684 & $\mathrm{I} 20$ & .695 \\
$\mathrm{I} 23$ & .647 & $\mathrm{I} 2$ & .699 \\
$\mathrm{I} 13$ & .623 & $\mathrm{I} 4$ & .655 \\
$\mathrm{I} 27$ & .624 & $\mathrm{I} 17$ & .655 \\
$\mathrm{I} 10$ & .681 & $\mathrm{I} 11$ & .738 \\
$\mathrm{I} 25$ & .596 & $\mathrm{I} 37$ & .598 \\
$\mathrm{I} 15$ & .639 & & \\
$\mathrm{I} 8$ & .592 & &
\end{tabular}

The results indicated that the TPUWL scale's item-total correlation values range between .575 and .738. These values indicate that each item is appropriate to be used in the TPUWL scale (Field, 2009; Büyüköztürk, 2006).

\section{Item Discrimination}

Table 6. Item Discrimination

\begin{tabular}{|c|c|c|c|}
\hline \multicolumn{2}{|c|}{ Factor 1: PU (12 items) } & \multicolumn{2}{|c|}{ Factor 2: PCP (10 items) } \\
\hline Items & $\begin{array}{l}\text { t-value (bottom 27\%, top } \\
27 \% \text { ) }\end{array}$ & Items & $\begin{array}{l}\text { t-value (bottom 27\%, top } \\
27 \% \text { ) }\end{array}$ \\
\hline I26 & $11.380 * *$ & $\mathrm{I} 12$ & $11.648 * *$ \\
\hline $\mathrm{I} 24$ & $9.880 * *$ & $\mathrm{I} 1$ & $11.544 * *$ \\
\hline I33 & $8.849 * *$ & I5 & $10.534 * *$ \\
\hline $\mathrm{I} 32$ & $8.555^{* *}$ & $\mathrm{I} 3$ & $8.995 * *$ \\
\hline $\mathrm{I} 22$ & $10.573 * *$ & $\mathrm{I} 20$ & $11.900 * *$ \\
\hline $\mathrm{I} 23$ & $10.846^{* *}$ & $\mathrm{I} 2$ & $10.883^{* *}$ \\
\hline I13 & $8.750 * *$ & I4 & $9.966 * *$ \\
\hline I27 & $8.562 * *$ & $\mathrm{I} 17$ & $11.005^{* *}$ \\
\hline I10 & $9.802 * *$ & I11 & $12.636 * *$ \\
\hline $\mathrm{I} 25$ & $9.111 * *$ & $\mathrm{I} 37$ & $9.768 * *$ \\
\hline I15 & $9.955 * *$ & & \\
\hline I8 & $9.476 * *$ & & \\
\hline
\end{tabular}
difference in scores for all items (Wiersma \& Jurs, 1990).

Independent group samples t-test was applied to compare the total scores of bottom $(27 \%)$ and top $(27 \%)$ groups on each item and evaluate the significant differences for all items between the groups. Also, correlation between TPUWL scale and its subscales was examined to determine their relationship(s) with each other. 
Table 7. Correlation of TPUWL Scale with subscales

\begin{tabular}{llll}
\hline & TPUWL Scale & PU & PCP \\
\hline TPUWL Scale & - & & \\
PU & .90 & - & \\
PCP & .86 & .56 & - \\
\hline$*$ & P $<.01$ & &
\end{tabular}

Correlation between TPUWL and its subscales are shown in Table 7. It is revealed by the data that scale has significant positive relation with its subscales.

\section{Findings on Scale's Reliability}

Every analysis case was examined to determine the reliability of the scale. To develop TPUWL scale data were gathered from 240 teachers and an internal reliability analysis was carried out. Results of analyses for each factor are indicated in Table 8.

Table 8. Internal consistency values of the TPUWL scale

\begin{tabular}{ll}
\hline Construct & Cronbach's $\alpha$ \\
\hline TPUWL Scale & .95 \\
Perception towards Using (PU) & .93 \\
Professional Competence Perception (PCP) & .94 \\
\hline
\end{tabular}

The Cronbach's Alpha values for the entire TPUWL scale, PU, and PCP were found to be .95, .93 , and .94 respectively. To confirm the reliability of TPUWL scale a second set of data were gathered from 220 teachers and an internal reliability analysis was carried out. Results of analyses for each factor are indicated in Table 9.

Table 9. Internal consistency values of the TPUWL scale

\begin{tabular}{ll}
\hline Construct & Cronbach's $\alpha$ \\
\hline TPUWL Scale & .96 \\
Perception towards Using (PU) & .94 \\
Professional Competence Perception (PCP) & .96 \\
\hline
\end{tabular}

As shown in Table 8 and Table 9, Cronbach Alpha values of the TPUWL scale and its subscales were greater than 0.70 (Tavşancıl, 2002), meaning that both overall scale and factor structures of scale have good reliability coefficients.

\section{Findings on Scale's Stability}

Stability of the scale was analysed through the data obtained during two different time intervals. Stability of the scale was shown in Table 10 with respect to Cronbach's Alpha $(\alpha)$, Correlation Between Forms (CBF), Spearman-Brown Coefficient (SBC), Guttman Split-Half Coefficient (GSHC) values for factors and overall scale.

Table 10. Stability of Scale

\begin{tabular}{lllllllll}
\hline & Interval I & \multicolumn{9}{c}{ Interval II } \\
\hline & $\alpha$ & CBF & SBC & GSHC & $\alpha$ & CBF & SBC & GSHC \\
\hline PCP &, 960 &, 894 &, 944 &, 944 &, 940 &, 863 &, 926 &, 926 \\
PU &, 940 &, 865 &, 928 &, 927 &, 960 &, 897 &, 945 &, 945 \\
Overall &, 961 &, 663 &, 797 &, 797 &, 962 &, 676 &, 807 &, 807 \\
\hline
\end{tabular}

Data in Table 10 reveals that overall scale which consists of 22 items and two factors has 
stability values for Interval I; .961 for Cronbach's Alpha; .663 for Correlation Between Forms; .797 for Spearman-Brown Coefficient and .797for Guttman Split-Half Coefficient. Stability values for the "Perception towards Using" factor are .940 for Cronbach's Alpha; .865 for Correlation Between Forms; .928 for Spearman-Brown Coefficient and 927 Guttman Split-Half Coefficient. Stability values for the "Professional Competence Perception" factor are .960 for Cronbach's Alpha; .894 for Correlation Between Forms; .944 for SpearmanBrown Coefficient and .944 Guttman Split-Half Coefficient.

Indicated values for Interval II are; 962 for Cronbach's Alpha; .676 for Correlation Between Forms; .807 for Spearman-Brown Coefficient and .807 for Guttman Split-Half Coefficient. Stability values for the "Perception towards Using" factor are .960 for Cronbach's Alpha; .897 for Correlation Between Forms; .945 for Spearman-Brown Coefficient and .945 Guttman Split-Half Coefficient. Stability values for the "Professional Competence Perception" factor are .940 for Cronbach's Alpha; .863 for Correlation Between Forms; 926 for SpearmanBrown Coefficient and .926 Guttman Split-Half Coefficient.

\section{Findings on Scale's Correlation Values}

Table 11. Pearson correlation between scale and factors

\begin{tabular}{llll}
\hline & TPUWL Scale & PU & PCP \\
\hline TPUWL Scale & 1 & $.917^{*}$ & $.899^{*}$ \\
PU & $.917^{*}$ & 1 & $.633^{*}$ \\
PCP & $.899^{*}$ & $.633^{*}$ & 1 \\
\hline
\end{tabular}

Pearson product moment correlation analysis was applied to examine the relationship between the scale and the factors. Analysis has revealed that there is a positive and significant relationship between the scale and factors. Significance level of TUPWL and sub-scales is determined by .01 and correlation degrees are taken into account when determining the correlation of the scale with its subscales. A 1.00-0.70 value indicates high correlation; .0700.30 indicates medium correlation; 0.30-.0.00 value indicates low correlation (Büyüköztürk, 2005). These results suggest that there is a high probability of an individual who gets a high score from a subscale will also get a high score from overall scale or vice versa. On this aspect, comparative analyses were carried out with respect to total scores obtained from the scale.

ANOVA and t-test results for the sample group with respect to age, education level, experience and gender are given in the tables shown below for TPUWL scale scores.

Table 12. ANOVA Results of TPUWL Scale with respect to age

\begin{tabular}{llllll}
\hline & Sum of Squares & df & Mean square & f & p \\
\hline Between groups & 185.967 & 2 & 92.984 & .481 & .619 \\
Within groups & 41959.669 & 217 & 193.363 & & \\
Total & 42145.636 & 219 & & & \\
\hline
\end{tabular}

Data in Table 12 reveals that there is no significant relationship $(F(2,217)=.481, \mathrm{p}>.05)$ between age and perception of teachers towards usage of Web 2.0 tools. This result draws the conclusion that teachers' perceptions towards using Web 2.0 tools are not affected by age factor. 
Table 13. ANOVA results of TPUWL Scale with respect to Education Level

\begin{tabular}{llllll}
\hline & Sum of Squares & $\mathrm{df}$ & Mean square & $\mathrm{f}$ & $\mathrm{p}$ \\
\hline Between groups & 35.433 & 2 & 17.716 & .091 & .913 \\
Within groups & 42110.204 & 217 & 194.056 & & \\
Total & 42145.636 & 219 & & & \\
\hline
\end{tabular}

Data in Table 13 reveals that there is no significant relationship $(F(2,217)=.091, \mathrm{p}>.05)$ between education level and perception of teachers towards usage of Web 2.0 tools. This result draws the conclusion that teachers' perceptions towards using Web 2.0 tools are not affected by education level factor.

Table 14. ANOVA results of TPUWL Scale with respect to Experience

\begin{tabular}{|c|c|c|c|c|c|}
\hline & $\begin{array}{l}\text { Sum } \\
\text { Squares }\end{array}$ & $\mathrm{df}$ & Mean square & f & $\mathrm{p}$ \\
\hline Between groups & 90.239 & 2 & 45.120 & .233 & .793 \\
\hline Within groups & 42055.397 & 217 & 193.804 & & \\
\hline Total & 42145.636 & 219 & & & \\
\hline
\end{tabular}

Data in Table 14 reveals that there is no significant relationship $(F(2,217)=.233, \mathrm{p}>.05)$ between experience and perception of teachers towards usage of Web 2.0 tools. This result draws the conclusion that teachers' perception towards using Web 2.0 tools are not affected by experience factor.

Table 15. T-test results of TPUWL Scale with respect to Gender

\begin{tabular}{lllllll}
\hline Gender & $\mathrm{n}$ & $\mathrm{x}$ & $\mathrm{s}$ & $\mathrm{sd}$ & $\mathrm{t}$ & $\mathrm{p}$ \\
\hline Male & 55 & 83.96 & 17.11 & 218 & 2.347 & .020 \\
Female & 165 & 88.98 & 12.41 & & & \\
\hline
\end{tabular}

Data in Table 15 reveals that there is a significant relationship $(\mathrm{t}(218)=2.347, \mathrm{p}<. .05)$ between gender and perception of teachers towards usage of Web 2.0 tools. This result, in light of descriptive statistics shown in Table 9, points to the fact that teachers' perceptions towards using Web 2.0 tools are affected by gender factor and female teachers have more positive perceptions than male teachers.

\section{Discussion and Conclusion}

The aim of this study is to develop "a scale to determine teachers' perceptions towards usage of web 2.0 tools" and to reveal the factors which affect these perceptions towards using Web 2.0 tools. First aim of the study is fulfilled since "determining teachers' perceptions on using Web 2.0 tools" scale is developed. Validity and reliability analyses of the TPUWL scale were carried out through two different samples which consisted of 460 teachers in total. Varimax results analyses indicated that two factors emerged for the TPUWL scale. Briggs \& Cheek (1986) point out that similarity of items which present themselves under a structure could be named through the factor name. Similarly, Williams, Onsman \& Brown (2010) argue that a meaningful induction of items under a factor structure could be named by the studies. Through the analyses it was understood that the items represent the image of teachers related to the process of Web 2.0 tools and their meaning in educational settings assembly under a structure. Whence, researchers of this study determined that the items under this factor structure could be named as Perception towards Using (PU) for the first factor since items under this factor mostly present perceptions of teachers towards using the Web 2.0 tools. However, items under the second factor mostly present the job related attributes and 
competence related to profession. Hence, the second factor was named as Professional Competence Perception (PCP).

Those factors are named as PU and PCP. Shared variance by the factors was $61.818 \%$ and scale's internal consistency Cronbach's Alpha value was .95. Internal consistency Cronbach's Alpha value for PU determined as .93 for PU and .94 for PCP. Since reliable scales has internal consistency Cronach's Alpha value above the 0.80 then TPUWL scale is also confirmed as a reliable one (Field, 2009; Kline, 1999).

In Addition, CFA, CFI, IFI, and NFI had the values above 0.90, and indicated a high modeldata fit (Hooper et al., 2008; Sümer, 2000). Likewise, the SRMR value (0.040) was above 0.05 and indicated a high model-data fit (Anderson \& Gerbing, 1984; Sümer, 2000; Hu \& Bentler, 1999). RMSEA value (0.072) was less than 0.08, indicating that model-data fit was acceptable (Anderson \& Gerbing, 1984; Hooper et al., 2008; Jöreskog\&Sörbom, 1993; Sümer, 2000; Hu \& Bentler, 1999). In summary, the results of confirmatory factor analyses showed that TPUWL scale has two-factor structure and high model-data compatibility (Anderson \& Gerbing, 1984). All these results indicated a valid and reliable TPUWL scale.

The second purpose of the study was to determine factors which affect teachers' perceptions. Thus, teachers' perceptions towards using Web 2.0 tools are analysed with respect to age, education level, experience and gender factors. Data analyses revealed that teachers' perceptions are not affected significantly by the factors of age, education level and experience. Almekhlafi and Abulibdeh (2018) also revealed that K-12 teachers' perceptions towards using Web 2.0 tools are not affected by the experience of teachers. Thus, results of this study, on this perspective, are consisted with these results. There are similar results shared in the literature (Lekan Kamil, 2014). On the other hand, literature also reveals opposing results with respect to age, experience and education level towards using Web 2.0 tools. For example, Horzum (2010) analysed the effect of experience with as to factors such as having knowledge upon the Web 2.0 tools, usage frequency, and purpose of usage. The results announced that usage of Web 2.0 tools and experience factors are related which contradict with the results of this study. In a similar vein, Soomro, Zai and Jafri (2015) pronounced that perceptions towards using Web 2.0 tools are affected by age. Another study by Batsila, Tsihouridis, Vavougios and Ioannidis (2015) showed perceptions towards usage of Web 2.0 tools are impacted by experience. These results contradict with our results.

The findings pertinent to the second purpose of the study revealed that perceptions towards using Web 2.0 tools are affected by gender factor. Similar results are also indicated in the literature. For example, Horzum (2010) declares knowledge upon usage of Web 2.0 tools, usage frequency and usage purpose are affected by gender factor which complies with the results of our study. Soomro, Zai and Jafri (2015) used a different approach and questioned usage and competency on Web 2.0 tools in the faculties. The related results indicated gender has influence on the usage. Batsila, Tsihouridis, Vavougios and Ioannidis (2015) also stated gender is effective on the usage of Web 2.0 tools. Zelick (2013) analysed academicians' perceptions on usage of Web 2.0 tools and pinpointed that these are affected by gender factor. Although studies mentioned above show similar results to those of our study, literature also indicates contradicting study results about gender factor. For example, Özerbaş and Mart (2017) studied English teacher candidates' perceptions towards usage of Web 2.0 tools and they did not detect any significant effect of gender on perceptions related to the usage of Web 2.0 tools. In a similar fashion, Almekhlafi and Abulibdeh (2018)'s study found out no effect of gender on K-12 teachers' perceptions towards using Web 2.0 tools. 
Due to Covid-19 an emergency lockdown has been put in effect around the world almost by all of the countries (Dunford, Dale, Stylianou, Lowther, Ahmed \& Torre Arenas, 2020). A similar approach adopted by Turkey and hence immediate precautions were taken account. For instance, on 12 March 2020 minister of Ministry of National Education has announced both on Periscope TV and Twitter that all the schools in the country will continue their education through distance education (MEB, 2020a), and Council of Higher Education stopped face to face course instruction on 13 March 2020 for universities (CHE, 2020). Even recently, President of the Republic of Turkey had a live meeting on 26 June 2020 with high school students on YouTube channel (TCBB, 2020). Such cases indicate that Web 2.0 tools used effectively by the states and officials, and as a consequence Web 2.0 tools have become an important subject for education settings and the states.

Taking a glance upon the Ministry of National Education's (MNE) distance education system will also enhance the comprehension of the importance of Web 2.0 tools within the education settings. MNE has announced that interactive courses will be taken through EBA TV (an online and interactive television-like software) which was developed by MNE for primary, elementary and high school levels. Lesson schedules were announced through EBA TV which has different portals for teachers, students, and parents (IETGD, 2020). Teachers were required to complete the missing lessons via EBA TV. Being unprepared to Covid-19 precautions and not having knowledge upon the Web 2.0 tools, some teachers used other platforms which in turn caused an official warning to the teachers by the MNE to use EBA TV. Consequently, school principals are required to establish and control EBA TV classrooms. That case naturally indicated that not only teachers need to have knowledge upon the Web 2.0 tools but also principals should (MEB, 2020b).

As a conclusion, it is believed that the importance of Web 2.0 tools for the states, teachers, principals and parents is critical. Thus, it is hoped that this study will enhance the contribution of the usage of Web 2.0 tools and related studies.

\section{Limitations of the Study and Suggestions}

This study aimed to develop a TPUWL scale to assess teachers' perceptions towards using Web 2.0 tools. Thus, the very study examined teachers' perceptions of using Web 2.0 tools based on factors of age, gender, education level and experience. A further study might be done to investigate whether branches (teaching areas) are influential in the development of perceptions or not. Reliability and validity of TPUWL might be assessed through different samples as well.

\section{References}

Ajjan, H., \&Hartshorne, R. (2008). Investigating faculty decisions to adopt Web 2.0 technologies: Theory and empirical tests. The Internet and Higher Education, 11 (2), 71-80. https://doi.org/10.1016/j.iheduc.2008.05.002

Akpınar, Y. (2003). Öğretmenlerin yeni bilgi teknolojileri kullanımında yükseköğretimin etkisi: İstanbul okulları örneği [The effects of higher education on teachers' use of new technologies: The Case of Schools in Istanbul]. The Turkish Online Journal of Educational Technology, 2 (2), 79-96. http://www.tojet.net/articles/v2i2/2211.pdf

Almekhlafi, A.G., \& Abulibdeh, E.S.A. (2018). K-12 teachers' perceptions of Web 2.0 applications in the United Arab Emirates. Interactive Technology and Smart Education, 15 (3), 238-261. https://doi.org/10.1108/ITSE-11-2017-0060 
Anderson, J. C., \&Gerbing, D. W. (1984). The effect of sampling error on convergence, improper solutions, and goodness-of-fit indices for maximum likelihood confirmatory factor analysis. Psychometrika, 49 (2), 155-173. DOI: https://doi.org/10.1007/BF02294170

Anyanwu, K. (2012). Teachers' perception concerning use of web 2.0 applications following professional development. (Unpublished Doctoral Dissertation). University of Houston. Texas.

Batsila, M., Tsihouridis, C., Vavougios, D., \& Ioannidis, G. (2015). Factors that influence the application of web 2.0 based techniques for instructional purposes: A case study. International Journal of Emerging Technologies in Learning, 10 (4), 1521.http://dx.doi.org/10.3991/ijet.v10i4.4529

Baumgartner, H., \& Homburg, C. (1996). Applications of structural equation modeling in marketing and consumer research: A review. International Journal of Research in Marketing, 13 (2), 139-161.

Bentler, P.M. (1980). Multivariate analysis with latent variables: Causal modeling. Annual Review of Psychology, 31, 419-456.

Birişçi, S., Kul, Ü., Aksu, Z., Akaslan, D., \& Çelik, S. (2018). Web 2.0 hızlı içerik geliştirme öz-yeterlik inancı belirlemeye yönelik ölçek (w2öyiö) geliştirme çalışması [A scale development study to determine web 2.0 practical content development self-efficacy belief (w2sebs)]. Educational Technology Theory and Practice, 8 (1), 187-208. DOI: https://doi.org/10.17943/etku.335164

Blannin, J. (2015). The role of the teacher in primary school Web 2.0 use. Contemporary $\begin{array}{llll}\text { Educational Technology, } & 6 & \text { (3), }\end{array}$ https://files.eric.ed.gov/fulltext/EJ1105760.pdf

Briggs, S.R. \& Cheek, J.M. (1986). The role of factor analysis in the development and evaluation of personality scales. Journal of Personality, 54 (1), 106-148. DOI: https://doi.org/10.1111/j.1467-6494.1986.tb00391.x

Brown, T. A. (2015). Confirmatory factor analysis for applied research (2nd Ed.). New York, NY: Guildford Press.

Büyüköztürk, Ş. (2006). Sosyal bilimler için veri analizi el kitabl: Istatistik, araştırma deseni SPSS uygulamalarl ve yorum [Data analysis handbook for social sciences statistics: Research design SPSS practices and interpretation] (6th ed.). Ankara, Turkey: Pegem.

Council of Higher Education (CHE). Koronavirüs (Covid-19) bilgilendirme notu: 1[Corona virus (Covid-19) information note: 1]. Retrieved from: https://www.yok.gov.tr/Sayfalar/Haberler/2020/coronavirus_bilgilendirme_1.aspx

Comrey, A. L., \& Lee, H. B. (1992). A first course in factor analysis (2nd ed.). Hillsdale, NJ: Erlbaum.

Dunford, D., Dale, B., Stylianou, N., Lowther, E., Ahmed, M. \& Torre Arenas, I. (2020). Coronavirus: The world in lockdown in maps and charts. Retrieved from: https://www.bbc.com/news/world-52103747 28 June 2020

Eyyam, R., Meneviş, İ., Doğruer, N. (2011). Perceptions of teacher candidates towards web 2.0 technologies. Procedia Social and Behavioral Sciences, 15, 2663-2666. DOI: https://doi.org/10.1016/j.sbspro.2011.04.166

Faize, R., Chiheb, R., \& Ee Afia, A. (2015). Students' perceptions towards using web 2.0 technologies in education. International Journal of Emerging Technologies in Learning (IJET), 10 (6), 32-36. DOI: http://dx.doi.org/10.3991/ijet.v10i6.4858

Field, A. (2009). Discovering statistics using SPSS (3nd ed.). California: SAGE

Friman, H., (1999). Perception warfare: a perspective for the future. Retrieved from http://media.leeds.ac.uk/papers/pmt/exhibits/746/Friman(1999)PW.pdf 
Hooper, D., Coughlan, J., \& Mullen, M. R. (2008). Structural equation modeling: Guidelines for determining model fit. Journal of Business Research Methods, 6 (1), 53-60. Retrieved from http://www.ejbrm.com/issue/download.html?idArticle=183

Horzum, M. B. (2010). Investigating teachers' Web 2.0 tools awareness, frequency and purposes of usage in terms of different variables. International Journal of Human Sciences (JHS), 7 (1), 603-634.

Horzum, M. B., \& Aydemir, Z. (2014). Web 2.0 tools and educational usage self-efficacy: A scale development study. Procedia-Social and Behavioral Sciences, 116, 453-458.

Hu, L.-T., \& Bentler, P. M. (1999). Cut off criteria for fit indexes in covariance structure analysis: Conventional criteria versus new alternatives. Structural Equation Modeling: A Multidisciplinary Journal, 6 (1), 1-55. DOI: https://dx.doi.org/10.1080/10705519909540118

Huang, W-H. D., Hood, D.W., \& Yoo, S.J. (2013). Gender divide and acceptance of collaborative web 2.0 applications for learning in higher education. The Internet and Higher Education, 16, 57-65. DOI:10.1016/j.iheduc.2012.02.001

Jöreskog, K. G., \& Sörbom, D. (1993). LISREL 8: Structural equation modeling with the simplis command language. Lincolnwood, IL: Scientific Software International.

Kaiser, H. F. (1960). The application of electronic computers to factor analysis. Educational and Psychological Measurement, 20, 141-151.

Kılıç, H. E., \& Şen, A. İ. (2014). UF/EMI eleştirel düşünme eğilimi ölçeğinin Türkçeye uyarlama çalışması [Turkish adaptation study of UF/EMI critical thinking disposition instrument]. Eğitim ve Bilim [Education and Science], 39 (176), 1-12. DOI: https://dx.doi.org/10.15390/EB.2014.3632

Kieffer, K. M. (1998). Orthogonal versus Oblique Factor Rotation: A Review of the Literature regarding the Pros and Cons. Paper presented at the annual meeting of the American Educational Research Association, New Orleans, LA.

Kline, P. (1994). An easy guide to factor analysis. London. England: Routledge.

Korucu, A. T., \& Yücel, A. (2015). Information technologies teachers' ideas about dynamic web technologies use in education. Educational Technology Theory and Practice, 5 (2), 126-152. DOI: https://dx.doi.org/10.17943/etku.78815

Lekan Kamil, Q. (2014). Teachers' perceptions and attitudes toward the implementation of web 2.0 tools in secondary education. (Unpublished Doctorate Thesis). Walden University, Minnesota.

Madans, J. H. (2001). Health Surveys. International Encyclopedia of the Social \& Behavioral Sciences, 6619-6627. DOI:10.1016/b0-08-043076-7/03903-6

Madden, T. J., Ellen, P. S., \& Ajzen, I. (1992). A Comparison of the Theory of Planned Behavior and the Theory of Reasoned Action. Personality and Social Psychology Bulletin, 18(1), 3-9. DOI: https://dx.doi.org/10.1177/0146167292181001

MEB. (2020a). Bakanımı Sayın Ziya Selçuk, küresel ölçekte etkili olan "yeni tip korona virüs"e karşı eğitim alanındaki tedbirler ve uzaktan eğitim sürecine ilişkin detayları açıllyyor [Minister Mr. Ziya Selçuk explains the details about the precautions related to education and distance education processes against the "new type of corona virus" which is effective on global scale]. Retrieved from https://twitter.com/tcmeb/status/1238163265462710272

MEB. (2020b). EBA'DA canli sinifla eğitim başliyor [Education start with live classrooms on EBA]. Retrieved from http://www.meb.gov.tr/ebada-canli-sinifla-egitimbasliyor/haber/20602/tr

O'Reilly, T. (2005). What is web 2.0: Design patterns and business models for the next generation of software. Retrieved from: http://oreilly.com/web2/archive/what-is-web20.html 
Özerbaş, M. A., \& Mart, Ö. A. (2017). Pre-service English teachers' opinions and utilization levels on the use of web 2.0. Ahi Evran University Kirşehir Education Faculty Journal, 18 (3), 1152-1167.

Rodríguez Bolívar, M.P. Policy makers' perceptions on the transformational effect of Web 2.0 technologies on public services delivery. Electron Commer Res 17, 227-254 (2017). DOI: https://doi.org/10.1007/s10660-015-9196-1

SPSS Statistics (Version 21) [Computer software]. Chicago, IL: SPSS.

Soomro, K.A., Zai, S.Y., \& Jafri, I. H. (2015). Competence and usage of Web 2.0 technologies by higher education faculty. Journal Educational Media International, 52 (4), 284-295. https://doi.org/10.1080/09523987.2015.1095522

Sümer, N. (2000). Yapısal eşitlik modelleri: Temel kavramlar ve örnek uygulamalar [Structural equation models: Basic concepts and sample applications]. Türk Psikoloji Yazılarl [Turkish Psychological Articles], 3 (6), 49-74. Retrieved from https://www.researchgate.net/publication/281981476_Yapidotlesssal_esitlik_modeller i_Temel_kavramlar_ve_ornek_uygulamalar

Tavşanc1l, E. (2002). Tutumların ölçülmesi ve spss ile veri analizi [Attitude measurement and data analysis with SPSS]. Ankara, Turkey: Nobel.

TCBB. (2020). Cumhurbaşkanı Erdoğan'ın, YKS'ye girecek öğrencilerle video konferans aracılığıyla yaptığı görüş̧me [President Erdoğan's video conference meeting with students who will take the YKS]. Retrieved from https://www.youtube.com/watch?v=nhXz8783eOU

Venkatesh, V., Croteau, A-M., Rabah, J. (2014). Perceptions of effectiveness of instructional uses of technology in higher education in an Era of web 2.0. 47th Hawaii International Conference on System Sciences, Waikoloa, HI, USA. DOI: https://doi.org/10.1109/HICSS.2014.22

Williams, A., Onsman, A. \& Brown, T. (2010). Exploratory factor analysis: a five-step guide for novices. Journal of Emergency Primary Health Care (JEPHC), 8 (3), 1-13.

Yan, Y., Zha, X. and Yan, M. (2014). Exploring employee perceptions of Web 2.0 virtual communities from the perspective of knowledge sharing. Aslib Journal of Information Management, 66 (4), 381-400. https://doi.org/10.1108/AJIM-08-2013-0070

Innovation and Educational Technologies General Directorate, (IETGD) (2020). EBA TV ders yayın [EBA TV lesson broadcast]. Retrieved from: http://www.eba.gov.tr/

Yildırım, B. (2018). Adapting the teachers' efficacy and attitudes towards STEM scale into Turkish. Journal of Turkish Science Education, 15 (2), 54-6. DOI: https://dx.doi.org/10.12973/tused.10230a

Yıldırım, B., \& Selvi, M. (2015). Adaptation of STEM attitude scale to Turkish. Turkish Studies: International Periodical for the Languages, Literature and History of Turkish or Turkic, 10 (3), 1117-1130. DOI: https://dx.doi.org/10.7827/TurkishStudies.7974

Yuen, S. C., \& Yuen, P.K. (2010). Web 2.0 in education: Teachers' perceptions and perspectives. Creating Futures Through Technology Conferenc, Biloxi: Missisippi. Retrieved from https://www.slideshare.net/scyuen/web-20-in-education-teachersperceptions-and-perspectivres

Yuen, S. C. Y., Yaoyuneyong, G., \& Yuen, P. K. (2011). Perceptions, interest, and use: Teachers and web 2.0 tools in education. International Journal of Technology in Teaching \& Learning, 7 (2), 109-123.

Zelick, S. A. (2013). The Perception of web 2.0 technologies on teaching and learning in higher education: a case study. Creative Education, 4 (7), 53-93. DOI: http://dx.doi.org/10.4236/ce.2013.47A2010 